\title{
MUNICIPAL DIVORCES - THE UNDER RESEARCHED TOIPIC OF TERRITORIAL REFORMS IN EUROPE
}

DOI: https://doi.org/10.18509/AGB.2020.03

UDC: 347.627.2:[342.26:35.071.51(4)"1998/2018“"

\section{Pawel Swianiewicz}

University of Warsaw, Faculty of Geography and Regional Studies, Department of Local Development and Policy, Poland

corresponding author: pswian@uw.edu.pl

\begin{abstract}
Territorial-administrative organization belongs to the most important and highly debated topics of political geography. The paper focuses on boundary changes on a municipal level. Territorial amalgamation reforms have attracted a lot of attention of scholars from different disciplines, recently resulting also in meta-analyses of studies of impacts of those reforms. But the opposite process - of territorial fragmentation (splits or "divorces" of municipalities) has not attracted sufficient attention of academic community. And in the practice of Central and Eastern Europe this type of reforms has been at least equally frequent and equally important as territorial consolidation reforms. Immediately after 1989/1990 turn-over we could note massive territorial fragmentation in several countries of former Yugoslavia, Czechoslovakia, Hungary and some others. But also more recently, within last 20 years there have been several cases of "municipal divorces". The paper provides inventory and draws general picture of such changes in 7 countries of the region (Bulgaria, Czech Republic, Hungary, Lithuania, Poland, Romania, Slovakia, Slovenia) and discusses both factors beyond the divorce initiatives as well as possible consequences for local democracy and local public service provision.
\end{abstract}

Keywords: territorial reforms, local government, economy of scale, local democracy, Central and Eastern Europe

\section{INTRODUCTION}

Territorial-administrative re-organizations belong to the most important and highly debated topics of political geography. They have also attracted a lot of attention of scholars from other social sciences, including political science, public administration studies or economics. The importance of the topic in Europe is strengthened by numerous territorial decades implemented in various countries during last two decades. In this paper we focus on municipal tier, leaving aside territorial reforms on other (e.g. regional) levels.

\section{MUNICIPAL BOUNDARY REFORMS IN EUROPE 1998-2018}

If we define municipal territorial reform as a change in number of municipal governments exceeding $5 \%$ of the value at the beginning of the researched period, we discover that during last 20 years the map of local governments in Europe has been very far from being stable. Most of the changes has been going into direction of further territorial
This article discusses following issues:

- What has been scale of municipal territorial reforms in Europe during last two decades?

- What has been the role of splits of municipalities among different types of territorial reforms?

- What have been consequences of these reforms for capacity of local governments to deliver services as well as for local democracy?

- What has been typical discourse of the reforms promoted by proponents and opponents of the changes?

consolidation through the municipal amalgamations. Such reforms - implemented either as one-step reform or in a more incremental way throughout several years - can be identified in at least 19 European countries. As a result the total number of municipalities has been systematically shrinking (see table 1). 
Table 1. Number of municipal governments in Europe 1998-2018

\begin{tabular}{|l|l|}
\hline Year & Number of municipal governments \\
\hline 1998 & 114,500 \\
\hline 2010 & 110,000 \\
\hline 2014 & 106,500 \\
\hline 2018 & 101,800 \\
\hline
\end{tabular}

Source: data collected by Local Autonomy Index project [9] and survey of experts conducted within "Territorial reforms in Europe: project. Figures are rounded up to 100 and cover 41 European countries (all except of

Azerbaijan, Bosnia and Herzegovina, Byelorussia, Kosovo and Russia).

Note: numbers in the table are rounded-up to 100.

This type of reforms has been subject of numerous studies (e.g. [1], [12], [13]). Their consequences have been heavily researched, even if academics still have not reached the consensus on the impacts of amalgamation on costs, capacity to deliver services or local democracy. There are several recent publications on those issues, having character of meta-analysis of individual empirical studies, allowing to draw general conclusions (see e.g. [4], [5], [7], [16]).

But all of those studies almost entirely over-look the fact that the merger reforms are not the only type of municipal boundary changes. In the same period of 1998-2018 there have been at least 10 European countries in which number of municipalities increased rather than decreased (see table 2). It has been a consequence of numerous splits of municipal governments, when part of the municipality "divorced" from the existing territorialadministrative unit. This type of territorial changes has been almost a tabula rasa for academic empirical research in social sciences. And extensive review of international academic journals allowed to identify several hundred empirical studies of amalgamation reforms and their consequences, but only four studies of municipal splits ${ }^{1}$ [7].

Why municipal divorces are so much underresearched comparing to municipal amalgamations? There might be two major reasons. One that municipal splits are usually not a result of a conscious policy of central governments, but rather occur as a result of bottom-up pressure from local political elites and local communities. Therefore scholars interested in analysis of impacts of government policies concentrate on merger reforms rather than on municipal divorces. The second potential reason is geographical location. Merger reforms have been often introduced in countries which are close to the core of academic research. At the same time one may note that the vast majority of the countries enumerated in table 2 is located in Central and Eastern Europe, which is closer to semi-periphery of the academic research in social sciences.

Table 2. European countries in which number of municipal governments has increased in 1998-2018 period

\begin{tabular}{|l|c|c|c|c|}
\hline \multirow{2}{*}{} & \multicolumn{4}{|c|}{ Number of municipal governments in } \\
\cline { 2 - 5 } & 1998 & 2010 & 2014 & 2018 \\
\hline Bulgaria & 262 & 264 & 264 & 265 \\
\hline Croatia & 545 & 556 & 556 & 556 \\
\hline Czech Republic & 6242 & 6250 & 6253 & 6258 \\
\hline Lithuania & 58 & 60 & 60 & 60 \\
\hline Montenegro & 21 & 21 & 23 & 23 \\
\hline Romania & 2948 & 3181 & 3181 & 3181 \\
\hline Slovakia & 2878 & 2890 & 2890 & 2890 \\
\hline Slovenia & 203 & 221 & 223 & 223 \\
\hline Spain & 8108 & 8115 & 8118 & 8124 \\
\hline Sweden & 288 & 290 & 290 & 290 \\
\hline
\end{tabular}

Several splits could be observed in Central and Eastern Europe in the early 1990s (e.g. in the Czech Republic, Slovakia, Hungary). But also in following years, individual cases of municipal splits have been quite common in several countries in the Eastern part of the continent. Those territorial changes introduced within last two decades are in the focus of the following sections of this article.

\footnotetext{
${ }^{1}$ The list includes two studies of municipal splits in Australia [2], [3], one in Brazil [10] and one in Poland [14].
} 
MUNICIPAL DIVORCES IN CENTRAL AND EASTERN EUROPE - BASIC FACTS

Figure 1 illustrates the number if municipal divorces in several countries of Central and Eastern Europe. The list of countries on figure 1 is not identical as in table 2 above, since in some of the countries the total number of municipal governments did not change, or even decreased, in

spite of cases of splits. The case of Ukraine is a good illustration of such a process. There were several (more than 150) cases of splits until 2013, but still on-going territorial reform after 2014 has led to the overall reduction in number of local governments between 1998 and 2018.

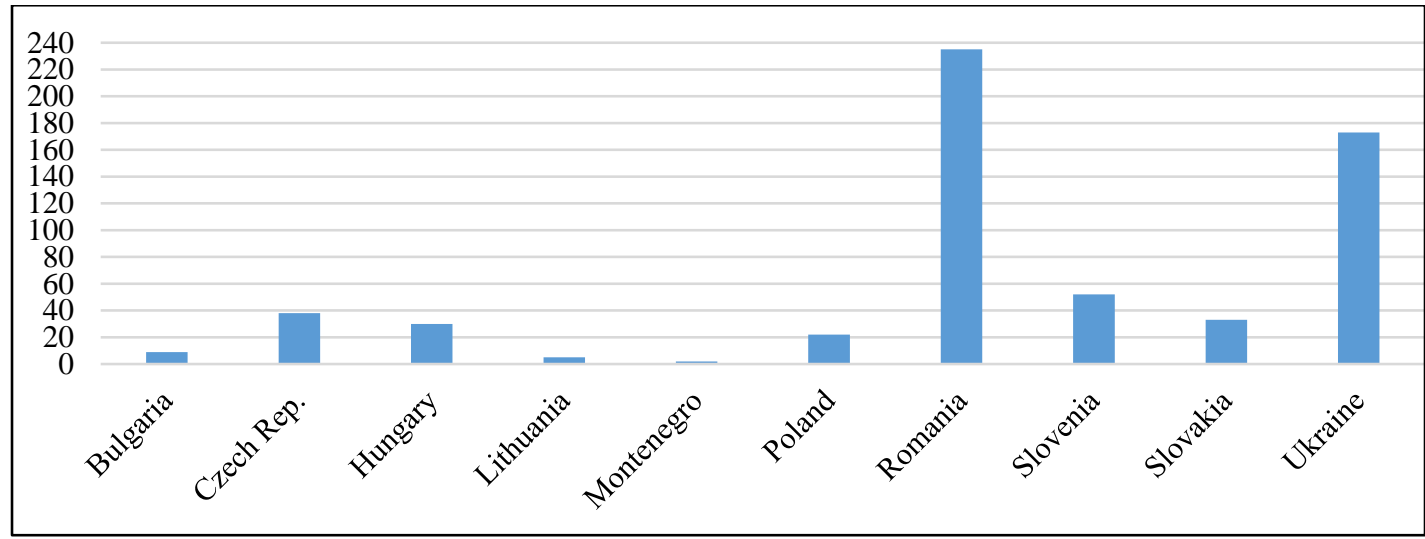

Figure 1. Total number of new municipalities in 1995-2018

As it is clear from figure 2, most of cases of municipal divorces took a place around the millennium, with a sharp decrease in number of new cases after 2005, and especially in recent years. What are the new municipalities emerged as a result of the divorces like? In order to answer this question, we have created a data base of 435 municipal splits which took a place in 8 countries of Central and Eastern Europe in 1995-2018 period. Slightly more than half of all of those cases refer to Romania.

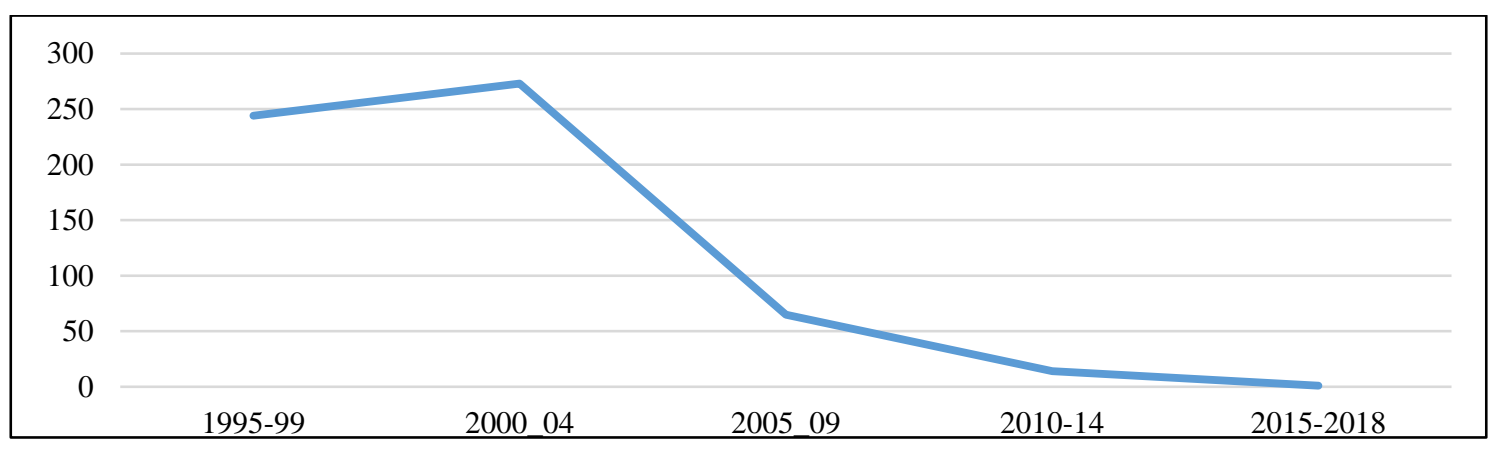

Picture 3. Reconstruction of the Skopje city structure from 1890 г. [31]

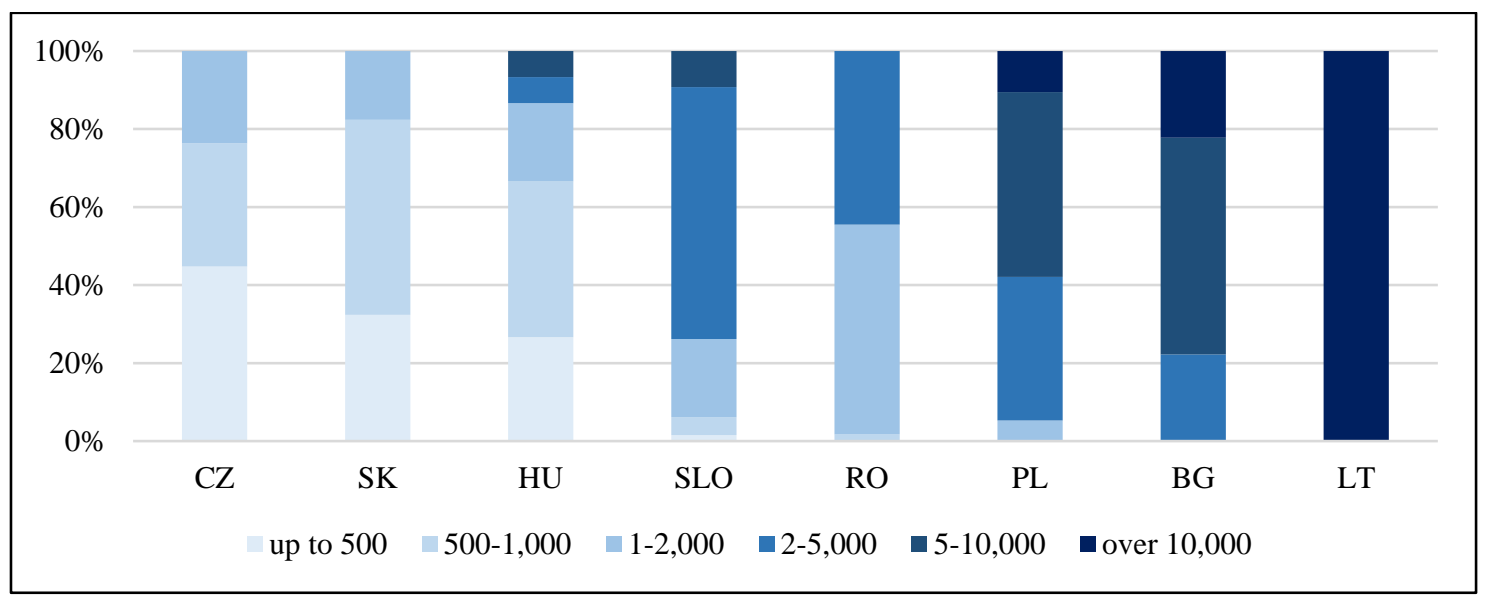

Figure 3. Population size of new municipalities 
On the basis of collected data we may say that first of all the newly created municipalities strongly vary in terms of their population size (see fig. 3). Czech Republic and Lithuania provide two opposite extremes. In the Czech Republic over three quarters of new municipalities are extremely small, with population below 1,000. Slovakia and Hungary follow similar model, although in the latter case the size of new territorial units is more diversified. At the same time new local government units created in Lithuania (and to a lesser extent in Bulgaria) are relatively big, inhabited by several thousands of population each. The most diversified is the size of new units in Slovenia and Poland.

Another difference between countries is related to the relative size of the "initiator of the split" and the "abandoned unit" (see fig. 4). As a rule, the initiator is a smaller part of the former municipality, which wants to break from the "bigger brother". However, there are also exceptions to this rule. In $8 \%$ of 435 analysed cases the split "initiator" is smaller from the "abandoned" municipality. Such situations are relatively the most often in Romania and Poland, although even in those countries they are only a tiny minority of all analysed cases. In another $1 / 3$ of all cases the "initiator" has been smaller than the "abandoned" municipality, but the difference of size has been relatively small - less than two times. In the remaining almost $60 \%$ of cases the size of the unit which has initiated the split is much smaller form the remaining part of the former municipality. But the situation in this respect strongly differs among analysed countries. In the Czech Republic (to a smaller extent also in Slovakia and Hungary) the dominant model is a split of very small part of the much larger town. In majority of cases in those countries the population size difference between initiator and abandoned municipality is more than 10 times. In the remaining countries the analysed cased of either more diversified in this respect (Slovenia, Poland, Bulgaria) or the size of both parties of the split is more balanced (Lithuania, Romania).

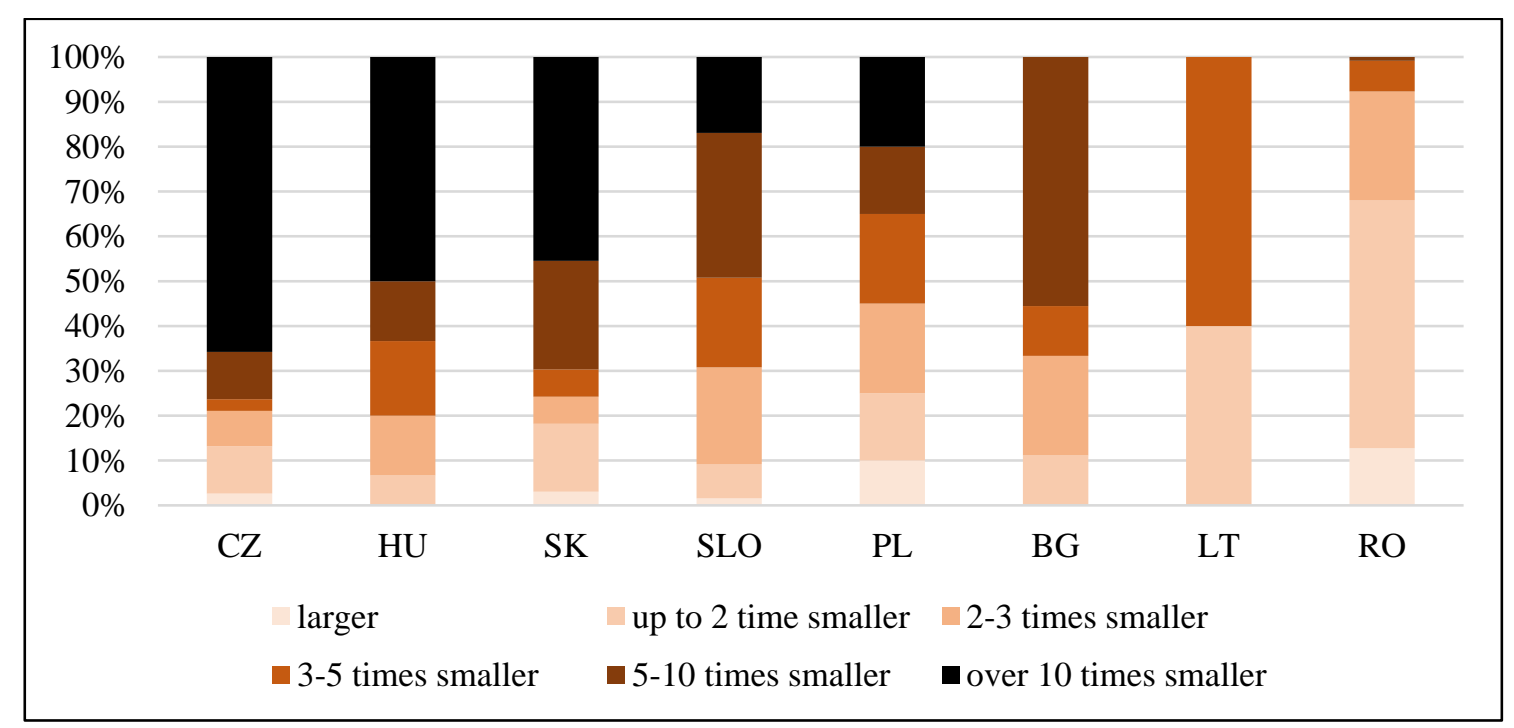

Figure 4. Ratio of population size of the new (initiator) to abandoned municipality

The data provided in this sections demonstrate that cases of splits are still common in Central and Eastern Europe, although their number has

\section{WHY THEY HAPPEN? REASONS AND ARGUMENTS FOR MUNICIPAL DIVORCES} In the early stage of political transition in Central and Eastern Europe the most common reason for the splits was a reaction for the forced amalgamation implemented under the communist regime. Such a reaction was identified in former Czechoslovakia and Hungary, but also in some of the countries emerged after collapse of Yugoslavia (see [1], [12]) and it led to very rapid increase in the number of municipalities in several countries (e.g. more than twofold in Hungary and more than four considerably decreased in recent years, and that they are very diversified phenomena revealing different features in individual analysed countries.

times in Croatia). But one cannot expect this factor to be decisive in later years of the end of 20th and the beginning of 21 st century. The most frequent reason for more contemporary "divorces" is related to the concept of heterogeneity within local government unit. Whether social heterogeneity of the local government unit supports efficiency of service provision is a controversial issue. According to some authors homogeneity increases managerial effectiveness [11]. The theory argues 
that small jurisdictions are more homogenous and therefore can offer policies that better match citizens' preferences. In addition, small bureaucracies allow for less distortion of citizen preferences [8]. But some authors argue that heterogeneity may lead to more efficient service provision [6]. However what is the most important for our discussion is that sometimes part of municipality has strong subjective feeling of being different from the rest of the local jurisdiction. This often leads to the perception of having divergent interests and being marginalized by the dominant "municipal centre", e.g. in decisions on new investments or service provision facilities. Poor physical access (proximity) to delivered services in the peripheral part of the municipality becomes a frequent argument for the "divorce". Such centrifugal forces would be especially strong if size difference between the "core of municipality" and "distinguished part" is large. Such disproportion of sizes strengthens feeling of being marginalized, since representation of the smaller part in the municipal council is not sufficiently strong to defend interest of their electoral wards.

Experts from nine countries ${ }^{2}$ have been asked to assess importance of various 25 pre-defined issues in the discourse accompanying splits of municipalities in their countries. The survey was conducted between December 2018 and January 2019. On the basis of their answers we have identified issues that have been the most often and the least often present in the debates related to changes of municipal boundaries. The most frequently discusses issues have been:

- Unequal treatment / discrimination of the smaller part of the municipality (mean score 4.1 in $1-5$ scale of importance)

- Proximity between citizens and their political

\section{EXPECTED IMPACTS?}

Data provided in the previous section tell us about perception of various issues related to territorial fragmentation being result of municipal splits. But this does not need to be identical with actual real impacts.

So what are the actual consequences of municipal divorces for effectiveness and efficiency of service delivery and for local democracy? Unfortunately there are very few empirical academic studies available in the literature, which would be based on solid methodological ground and which would study this important topic. There are several studies of the opposite processes - the impact of amalgamation reforms - but their results are helpful representatives (3.6)

- Restoration/ protection of local identity (3.6)

- Citizen participation in local governance (3.3.)

- Administrative capacity to deliver services (3.3)

- Costs of local administration (3.3.)

- Availability/proximity of local public services (3.2)

- Capacity of local government to promote local economic development (3.2)

- Economic resilience and financial management of municipality (3.1)

- The least debated issues include:

- Capacity for inter-municipal cooperation (mean score 1.2 in 1-5 scale of importance)

- Demographic trends (1.6)

- Match between administrative boundaries and catchment area of locally provided services (1.8)

- Capacity for strategic planning in municipality (1.8)

- Preservation of jobs in local administration (1.8) (on both lists the arguments raised mainly by opponents of the split are marked by italic font).

As it might be expected, arguments related to economy of scale theory are mostly raised by opponents of the municipal divorces, while issues related to functioning of local democracy and physical access to local public services by proponents of the secession of new municipalities. Interestingly, issues related to professional capacity of local administration - which in theory are expected to be used as arguments for territorial consolidation - have been raised to the same extent by proponents and opponents of municipal splits. Following theoretical concepts one might also expect that issues related to the recruitment of professional staff working for local administration should also be an argument against municipal splits. However in practice this argument is almost absent in most of local debates.

in answering our research questions to a limited extent only. We may ask if the results of local government splits are a mirror of the consequences of mergers, which have been studied earlier in various countries (mostly in Western Europe, USA, Australia and Japan). Can we expect to find negative consequences of splits in relation to variables in which positive consequences were observed after the mergers? And vice versa: are negative side-effects of mergers replaced by positive results of the splits? The answer for those questions has important theoretical consequences and may contribute to filling the gap in our knowledge on the relationship between size and

\footnotetext{
${ }^{2}$ Bulgaria, Croatia, Czech Republic, Hungary, Lithuania, Poland, Romania, Slovakia, Slovenia.
} 
service delivery as well as functioning of local democracy. The positive answer (i.e. finding symmetry between results of territorial fragmentation and consolidation) would strengthen the argument that the size really matters. If there is no symmetry, then one might speculate as to whether trends noted e.g. by studies of territorial amalgamation reforms in earlier studies were not related to the mere fact of the change (the reform). But so far the empirical evidences are scare in this respect.

Two studies of municipal "divorces" in Poland ([14], [15]) suggest that:

- Municipal splits usually lead to increase of the costs of administrative services,

- However their impact on costs of other services as well as financial management is much less clear, and - opposite to theoretical expectations arising from economy of scale theory sometimes may lead to positive changes,

- Splits result in higher electoral mobilization (increase of voter turnout in local elections). The change is visible in both parts of the split municipality, but it is stronger in the part which initiated the split. This may reflect an effect of enthusiasm, after achieving of the goal local community was fighting for;

- In spite of mobilisation of larger number of candidates, the level of electoral competition drops in the split municipalities. It means that the smaller size being the consequence of the split may support citizens participation, but it creates problems for the Schumpeterian model of procedural democracy based on competition. However, these conclusions are based on very limited empirical base, restricted to one country only. As it was demonstrated earlier in this article, the models of municipal splits strongly vary both among countries and within individual countries. The split of very tiny village (with just a few hundreds of residents) from dozen times larger municipality may have very different consequences than "divorce" of two parts of the municipality of similar sizes, each of them populated by several thousand citizens. Variation of consequences may also depend on the set of functions local governments are responsible for in a given country, inter-governmental financial architecture, level of organizational autonomy etc.

It all suggests that this article uncovers just a top of an ice-berg of very much under-researched phenomenon. Much more effort related to international comparative studies involving countries with different models of local government systems is required in order to understand better the phenomenon of municipal splits and their consequences.

\section{ACKNOWLEDGMENTS}

The paper is based on results of the "Territorial reforms in Europe - comparative perspective" research project. The project has been funded by Narodowe Centrum Nauki (National Science Centre) in Poland, grant number 2017/26/M/HS5/00152

\section{REFERENCES}

[1] Baldersheim, H. and Rose, L. Territorial choice: The politics of boundaries and borders, London: PalgraveMacmillan, 2010.

[2] Dollery, B., Kortt, M., \& Grant, B. 'A normative model for local government de-amalgamation in Australia'. Australian Journal of Political Science, vol. 46(4), pp. 601-615, 2011

[3] Drew, J., Dollery, B. 'Separation anxiety: an empirical evaluation of the Australian Sunshine Coast Regional Council de-amalgamation’, Public Money \& Management, vol. 34(3), pp. 213-220, 2014, DOI:10.1080/09540962.2014.908032

[4] Drew, J., Razin, E., Andrews, R. 'Rhetoric in municipal amalgamations: a comparative analysis', Local Government Studies, 2018 DOI: 10.1080/03003930.2018.1530657

[5] Ebinger, F., Kuhlmann, S., Bogumil, J. 'Territorial reforms in Europe: effects on administrative performance and democratic participation', Local Government Studies, 2018, DOI: 10.1080/03003930.2018.1530660

[6] Fox, W.F., Gurley, T. 'Will consolidation improve sub-national governments?', Policy Research Working Paper 3913, Washington: The World Bank, 2006.

[7] Gendźwiłl, A. Kurniewicz, A., Swianiewicz, P. 'The impact of municipal territorial reforms on economic performance of local governments: systematic review of quasi-experimental studies', paper presented at ECPR Annual Conference, Hamburg, 23-25 August, 2018.

[8] Hansen S.W. 'The democratic costs of size: how increasing size affects citizen satisfaction with local govewrnment', Political Studies, vol. 63, pp. 373-389, 2015 
[9] Ladner, A., Keuffler, N., Baldersheim, H., Hlepas, N., Swianiewicz, P., Steyvers, K., Navarro, C. Patterns of local autonomy in Europe, London: Macmillan, 2019.

[10] Lima, R.C. de Andradem Neto, R. da Mota Sileira. 'Secession of municipalities and economies of scale: evidence from Brazil', Journal of Regional Science, vol. 58, pp. 159-180, 2018.

[11] Ostrom, V, Tiebout, C, Warren, R. 'The Organization of Government in Metropolitan Areas: A Theoretical Inquiry', American Political Science Review, vol. 55(4), pp. 831-42, $1861 .$.

[12] Swianiewicz (ed.) Territorial reforms in Europe, Budapest: LGI-Open Society Institute, 2010.

[13] Swianiewicz, P. 'If territorial fragmentation is a problem, is amalgamation a solution? - ten years later', Local Government Studies, vol. 44(1), pp. 1-10, 2018.

[14] Swianiewicz, P., Łukomska, J. 'Is small beautiful? The quasi-experimental analysis of the impact of territorial fragmentation on costs in Polish local governments', Urban Affairs Review, 2017, https://doi.org/10.1177/1078087417744676.

[15] Swianiewicz, P., Gendźwiłł, A., Łukomska, J. ‘'Inicjatorzy i opuszczeni: demokracja lokalna po gminnych rozwodach', Prace Geograficzne, vol. 154, pp. 7-33, 2018.

[16] Tavares, A. F. 'Municipal amalgamations and their effects: A literature review', Miscellanea Geographica. Regional Studies on Development, vol. 22(1), pp. 5-15, 2018. 